\title{
How does Griya Batik Mas Pekalongan Promote their Products? The Strategy and its Obstacle
}

\author{
Robiatul Adawiyah ${ }^{1}$, Rina Suprina ${ }^{2}$, Meri Dwi Susanti ${ }^{3}$ \\ ${ }^{1,2,3}$ Sekolah Tinggi Pariwisata Trisakti, Jakarta, Indonesia \\ Email : ${ }^{1}$ robiyatul.adawiyah@stptrisakti.ac.id, ${ }^{2}$ rinasuprina@stptrisakti.ac.id
}

\begin{abstract}
Promotional strategies are steps determined by the company to achieve a company's goals. Batik is a genuine cultural heritage of Indonesia which is currently being enjoyed by the people of Indonesia. One of the batik producers in Java is located in Pekalongan City, Central Java. One of batik artisans in Pekalongan city is Griya Batik Mas. This study investigated the promotion strategy conducted by Griya Batik Mas and the obstacles in running the promotion strategy. The respondent is the owner of Griya Batik Mas Pekalongan. The focus of research is promotion strategy and inhibiting factors. The type of research is qualitative research and Methods of data collection are observation and interviews, followed by Interactive Analysis. The result showed that Griya Batik Mas has good promotional strategy used to keep increasing sales and increase the number of visitors who come to Griya Batik mas. However, the use of social media as a promotional tool is still lacking, so social media methods still need to be developed to be better. Griya Batik Mas needs to maintain the existing promotion strategy, as well as improve the ability to utilize social media as a means of promotion and continue to make the latest product innovations in accordance with the market interest.
\end{abstract}

Key words - Promotion Strategy, Batik, Marketing, Pekalongan, Griya Batik Mas.

\section{INTRODUCTION}

Batik is a craft culture from Indonesia that has been recognized by the international world, to be exact by UNESCO., on the $2^{\text {nd }}$ ctober 2009 . Since then the $2^{\text {nd }}$ October has officially become the national batik day. In Indonesia batik has various types and uniqueness according to the culture of the region. One of the most famous batik cities is Pekalongan, located in central Java. The city branding of Pekalongan is the World's City of Batik.

With the batik trend in the city of Pekalongan there are many batik shops, one of which is quite famous in Kampung Batik Kauman, namely Griya Batik Mas. Griya Batik Mas has been established since 1997 before Kampung Batik Kauman become a tourist village. Griya Batik Mas sells various typical Pekalongan batik motifs and ornaments made from batik. Griya Batik Mas is present as a form of responsibility in preserving the culture nation through the art of batik in particular and batik business in Indonesia in general.

Various promotional activities have been done by Griya Batik Mas to continue to grow and become more known by the outside community. In Kampung Batik Kauman there are many shops selling batik, but the people around show the place to shop batik only in Griya Batik Mas, so it is very interesting to know what is done by Griya Batik Mas, so the community also helped promote Griya Batik Mas to the visitors who come to Kampung Batik Kauman.

In doing business Batik business in the village of Batik Kauman, there are several issues that background the selection of this topic. The problem is that many batik business that stood in the village of kauman batik causing business competition, so in need of good promotion strategy in order to still be able to attract consumer interest, so the purpose of this research is to describe and evaluate the promotion strategy conducted by Griya Batik Mas as well as describe the constraints and supporting factors in running a promotional strategy to attract consumers, increase sales and preserve batik. 


\section{LITERATURE REVIEW}

\section{A. Promotion}

Shimp [2003: 111] suggests promotion refers to every incentives used by producers for the sale of goods and services. Meanwhile, according to Tjiptono [2002: 200] the promotion is: "All activities intended to convey or communicate a product to the target market, to inform the benefit, usability, and most importantly the existance of it to change attitudes and encourage people to buy.

\subsection{Promotion Mix}

According to Kotler and Armstrong [2012: 62], Promotion is the elements used to inform and persuade the market about a new product or service to the company through advertising, personal selling, sales promotion, or publicity. The promotional mix consists of 8 models summarized from Kotler and Keller [2012: 498-501] as follows:

The first one is advertising. It is all payable forms of nonpersonal presentation and promotion of ideas, goods or services through clear sponsorship through print media (newspapers and magazines), broadcast media (radio and television), network media (telephone, cable, satellite, wireless), and electronic media (sound recordings, video recordings, CD-ROMs, web pages), and exhibition media (billboards, signboards and posters). Second, Personal Selling, is a face-to-face interaction conducted by company salespeople with one or more prospective buyers for the purpose of conducting sales meetings, personal presentations, answering questions, order procurement, making sales, and customer relationships. Third, Sales Promotion, are short-term incentives to encourage experimentation or purchase of products or services including consumer promotions (such as samples, coupons, and premiums), trade promotions (advertising and benefits), and business and salesperson promotions for sales reputation). Fourth, Public Relations. It is a comprehensive communication efforts of a company to influence the perceptions, opinions, beliefs, and attitudes of various groups to the company [Tjiptono, 1997: 230]. Fifth, Events and Experiences, is a company-sponsored activity and program designed to create daily or brandspecific interactions with consumers, including sports arts, entertainment, and causing events or activities to be less formal. Sixth, Direct Marketing, is the use of mail, telephone, facsimile, e-mail, or the internet to communicate or connect directly by requesting a response or response and dialogue from customers and prospects. Seventh, Interactive Online Marketing, Online activities and programs designed to engage customers or prospects and directly or indirectly improve awareness of improving the image, or create sales of products and services. Eighth, Word of Mouth Marketing, is an oral, written, and electronic communication between communities that deals with excellence or the experience of buying or using a product or service.

\subsection{Consumer Behaviour}

Consumer behavior is the individual activities which directly involved in getting and using goods and services. It involves decision making in obtaining goods or services. Consumer behavior understanding search the answers to the questions such as what to buy, where to buy, how often, and under what condition the goods or services are bought. [Dharmmesta \& Handoko 2000]

\subsection{Place Marketing}

Place marketing is used for various purposes, such as building a positive image of a place and attract visitors, companies, institutions. Nowadays a place is needed to attract visitors as well as to search the market and to market the results of the industry produced by the venue. That requires a marketing management tool and the awareness toward the brand [Kotler \& Gertner 2002: 2534]. 


\section{METHODS}

This type of research is qualitative. According to Moleong [2011: 6] qualitative research is a study that intends to understand the phenomenon of what is experienced by research subjects such as behavior, perception, motivation, action and others, holistically, and by way of description in the form of words, in a special, natural context by utilizing various methods. It is categorized descriptive because it is a method that describes the variable by variable without trying to explain further the relationship between variables. Descriptive data collected in the form of words, images and not the numbers. In qualitative research the methods usually used to collect data are interviews and observations.

Data analysis method used is "descriptive qualitative analysis method" which according to Miles and Huberman Models [Sugiyono, 2014: 402] consists of 3 stages. The first stage is Data Reduction, which begins with findng and collecting the results of interviews and documentation related to Griya Batik Mas promotion strategy. The data collected from the informants will be grouped and the checking process is done through triangulation of data to be selected again based on needs and conformity with the research. The unnecessary data will be sorted / removed. The next step is simplification of data / research results through coding so that the data is easy to be understood and easily presented, which is summarized in the form of data reduction tables to facilitate the final conclusion. The second stage is Data Presentation, done by categorizing and arranging the data / information collected in order to get a complete and systematic picture to facilitate the conclusion and taking action. The presentation of the data used in this qualitative research is narrative text, either in the form of brief descriptions, charts, tables, relationships between categories, and easy-to-understand flowcharts. The third stage is the Withdrawal Conclusion, which is done when the researcher can summarize the promotional strategy that has been done, the constraints faced, and recommendation of appropriate promotion strategy to be applied in Griya Batik Mas.

\section{RESULT AND DISCUSSION}

\section{A. Kampung Batik Kauman}

Kampung Batik Kauman is the name of area, literally translated as Kauman Batik village, located in Pekalongan urban area, near town square of Pekalongan, Central Java. Kampung batik Kauman has been ratified as a tourist village, and since then many people in Kampung Batik Kauman open a showroom to sell their batik products. The data shows that there are 24 batik shop available in Kampung Batik Kauman. One of the biggest batik shop is Griya Batik Mas.

\section{B. Griya Batik Mas}

Griya Batik Mas is one of the most famous batik shop in Kampung Batik Kauman located at Gang 1 Jl. KH. Wahid Hasyim, Kauman, Pekalongan, Central Java 51127. Griya Batik Mas itself has been established since 1997 founded by Mr. H. Rosidi. In developing his business, Mr. H. Rosidi is assisted by his wife, Mrs. Aida, and his eldest son Mr. M. Hisham. Initially Griya Batik Mas only sold clothes taken from certain areas, namely Silk cloth, which was quite expensive. However, in that year there was a monetary crisis that required Griya Batik Mas to find another alternative that is by selling batik cloth from weaving or ATBM (Original Weaving, not a Machine) and it turns out a lot of enthusiasts. In developing his business from the past until now Griya Batik Mas always take advantage of existing momentum, such as participating in the training provided by local government in promoting its products. 
Griya Batik Mas business has now been run by the children of H. Rosidi , M. Hishyam, M. Nabil, M. Iqbal and Nita, so they share their respective duties. Figure 1 shows Griya Batik Mas's organizational structure

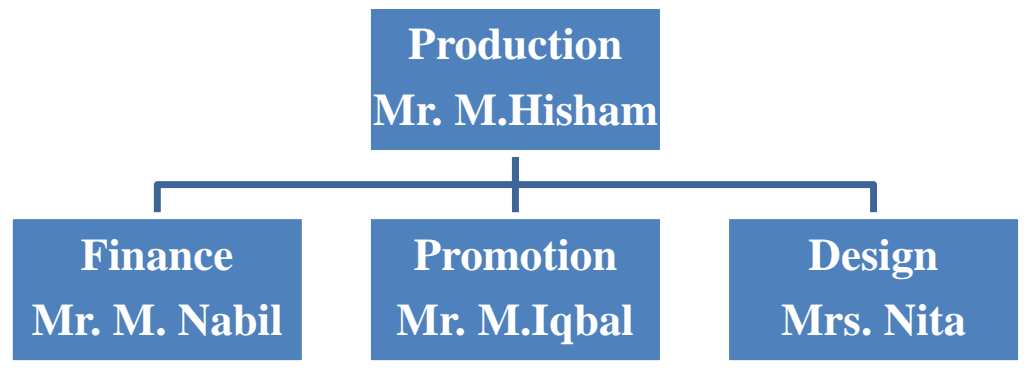

Fig.1 Griya Batik Mas Organizational Culture

1. Production

In running the business of Griya Batik Mas, Mr. M. Hisyam has a role as production manager. Production manager is a position in a company that is fully responsible in the production process in a company.

2. Finance

Mr. M. Nabil is the younger brother of Mr. Hisham who is in charge of planning, budgeting, checking, managing, and saving funds owned by Griya Batik Mas.

3. Promotion

Mr. M. Iqbal helped Griya Batik Mas business is in the field of promotion Griya Batik Mas. The tasks and responsibilities he has to take is to lead and be responsible for the whole process of marketing activities to achieve the company's goals

4. Design

Mrs Nita is the youngest sister of Mr. Hisham who serves as a designer who creates, and designs clothes, bags, accessories and all kinds of goods produced by Griya Batik Mas. Ibu Intan considers things that are the trend or something that is rampant in the market, so that all the items sold by Griya Batik Mas is the latest style because they always keep up with the era and look for something new.

\section{Product And Marketing}

Griya Batik Mas is a Traditional Batik Tulis company that produces Batik Tulis products that are processed naturally, using natural coloring material (natural) taken teger wood, tinggi wood, jambal wood and other natural materials obtained from the nature of Indonesia. In marketing its products Griya Batik Mas take advantage of tourist village that is "Kampung Batik Kauman" which offers various tourist facilities such as educational tour, ancient tourist tours, religious tourism, shopping tour, so these tours can be used as a draw for visitors to visit the village of Kauman.

\section{Promotion Strategies and Networks}

1. Promotion strategy and promotion network conducted by Griya Batik Mas are as follows: Using Internet channels /website

2. Using tourism events that exist in Pekalongan, especially in Kauman Batik Village where Griya Batik Shop is located. Some events are cultural tourism and batik tour attraction.

3. Making their own events related to batik such as learning to make batik with kindergarten children and training for people who are interested to learn how to make batik.

4. Joining exhibition activities such as INACRAFT's annual exhibition at Jakarta Convention 
Center.

\section{E. Evaluation of Griya Batik Mas Promotion Strategy}

Based on the explanation of external factors underlying the planning of promotion strategy Griya Batik Mas, it can be seen that in running its business, Griya Batik Mas always see the market situation and take advantage of momentum. Griya Batik Mas always tries to apply the market desire in every production. This is done so as not to accumulate goods because it is not sold. Griya Batik Mas should focus on promotional strategy by choosing which promotion strategy is most appropriate use among 8 model of promotion mix,

\section{F. Promotion Strategy of Griya Batik Mas based on 8 Modes of Promotional Mix.}

\section{Advertising}

Advertising used by Griya Batik Mas in offering products is to put ads on the website or through social media networks such as Instagram, Facebook and Zalora online store. In general, Griya Batik Mas displays the photos of their photos of batik collections to be sold. M. Iqbal who is in charge of promotion also put the address ofn Griya batik Mas shop so that users who see and are interested in the products marketed through social media networking can directly visit the location of Griya Batik Mas.

\section{Public Relation}

One of the promotional mix used by Griya Batik Mas in selling its products is public relations approach. The application of his actions is Mr. M. Hisham helping the promotion process undertaken by Mr. M. Iqbal by always following the activities held by Kampung Batik Kauman and plunging directly into the community to interact so that can be known about the needs of the community batik crafts are very often used by the community. Furthermore, the team of batik craftsmen from Griya Batik Mas can immediately realize the wishes of the community so that when people know that the required product can be found in Griya Batik Mas, they will directly buy it to Griya Batik Mas. Besides aiming to know the people's desire about batik craft often needed, other purpose of public relation activity is to promote the products that are sold in Griya Batik Mas outlet and try to convince the market that the products have good quality with the appropriate price.

\section{Personal Selling}

Promotional activities in the form of personal selling is a two way communication between buyers and sales person who work in Griya Batik Mas outlets. The sales persons give a persuasive greeting to buyers or prospective buyers who come to the shop. In this situation the sales persons can offer other products sold at the shop. As a result, when visitors have chosen a favored product, they will also becomes aware of other products being sold at the booth. The advantages of this promotional activity is a quick interaction with visitors and a lot of time allocation in persuading visitors to buy other products.

\section{Sales Promotion}

Sales promotion is a form of direct persuasion through the use of various incentives that can be set to stimulate purchases of products and increase the amount of goods purchased by customers. The purpose of sales promotion is very diverse. Through sales promotion, companies can attract new customers, influence their customers to try new products, encourage customers to buy more, attack competitors' promotional activities, improve impulse buying, or seek closer cooperation with retailers. Promotion activities in the form of sales promotion done when Griya Batik Mas held certain events or when taking part in batik exhibitions in various regions in Indonesia. Activities undertaken by sales promotion both men and women is to provide a brochure or leaflets to visitors who come to events or exhibitions followed by Griya Batik Mas. The purpose of this promotion is to sell batik, but the initial purpose of this promotion is so that people know in 
advance about Griya Batik Mas and products sold.

\section{Event and Experiences}

Event and Experiences promotion mix is selected as one of Griya Batik Mas's promotion strategy in increasing product sales. Related to this promotion mix, GRiya Batik Mas using bazaar as a media campaign because bazaar is considered perfect for Griya Batik Mas which has various products other than clothing. In this bazaar they can display all the products such as accessories and other decoration related to batik. Bazaar is very important because it becomes a promotional strategy that can make the customer reach the process of understand the product, desire to buy, and finally buy it as bazaar is able to provide an opportunity for consumers to see and try the product directly. Especially because Griya Batik Mas moves in the field of fashion, which to attract consumers is not enough just from seeing the promotion of products in social media, but rather to the physical form and product quality. Promotional and media forms on bazaar should be improved by Griya Batik Mas, among others: direct promotion aspect, product physical appearance, promotion media (brochure, business card, X-Banner). The shortcomings of the Griya Batik Mas bazaar to be improved are the stand / booth decoration, the type of promotion at the bazaar, and the type of bazaar. Choosing the right bazaar will increase brand image and the proud aspect of customers

\section{Direct Marketing}

The direct marketing / direct marketing promotion mix is important to be done by Griya Batik Mas in order to gain new customers and increase product sales. According to consumers, the direct marketing Griya Batik Mas do during this time when the bazaar is good and must be maintained. The form of direct offers / direct marketing should be done Griya Batik Mas, the first must pay attention to the ethics in direct marketing to consumers, which must be able to read the situation and condition of consumer (consumer privacy) and pay attention to modesty and professionalism. The second is direct marketing must be done with carrying, brochures, product catalogs, and business cards, complete product explanation, Griya Batik Mas contact person who can be contacted to make order, and also there is info about online social media Griya Batik Mas.

\section{Word of Mouth Marketing}

Word of Mouth Marketing is very possible to run to promote Griya Batik Mas products to friends / to others after they purchase the product. Plus, the type of information that can make customer Griya Batik Mas believe and decided to buy products GRiya Batik Mas so far one of them turned out to be Word of Mouth. The distributor company also does Word of Mouth to make customer more trust and try to buy Griya Batik Mas. Word of Mouth promotion mix as one of its promotional strategy that is effective because indirectly very helpful Griya Batik Mas in promoting the product from one person to another. Word of Mouth promotion form is not limited to conventional face to face but Griya Batik Mas can utilize online social media for WOM implementation in the form of testimony. Testimony in social media makes WOM easier to happen and more widespread.

\section{Interactive Online Marketing}

From the results of the research shows that the promotion mix of Interactive Online Marketing is chosen as one of promotion strategy that is important for Griya Batik Mas. Most consumers of GRiya Batik Mas apparently like to buy products online. Promotion strategy through Interactive Online Marketing is appropriate and should be a promotional strategy concept that should be improved Griya Batik Mas, because see Griya Batik Mas sells Fashion products and also see the target market Griya Batik Mas. Promotion through online media can be used to introduce brand and product, and make customer to know in advance with Griya Batik Mas product. By looking at the effectiveness of promotional costs (budget promotion), which most promotions through online media is very low cost and free to make Interactive Online Marketing suitable for Griya Batik Mas. Improved promotion strategy of Griya Batik Mas through Interactive Online Marketing one of them is by choosing certain social media of online 
which is most used and most recommended by resource person and make improvement on lack of promotion in social media online. Online social media selected to be improved as the focus of Griya Batik Mas promotion strategy is Instagram and Website.

\section{CONCLUSION AND RECOMMENDATION}

To be able to develop promotional activities in order to keep running effectively must perform the stages of identifying the target audience, determining promotional goals, designing messages, choosing promotional channels, setting total promotional budgets, deciding promotional mix, stalling promotional results, and managing integrated marketing communications processes. Promotional activities undertaken by Griya Batik Mas in attracting consumers to buy their products are required to conduct promotional activities by focusing on promotion mix that is:

1. Event and experience: with more bazaar activities and events that were raised only a few times in 1 year, should be upgraded to be once a month for promotion to be more eective.

2. Interactive Online Marketing: more improve again to keep updating information in social media owned by Griya Batik Mas.

3. Sales Promotion: To attract more people with the proo-promo or discount in Griya Batik Mas.

4. Word of Mouth Marketing: in the form of testimonials given by previous customers, which will make others curious so that people visit Griya Batik Mas.

Basically, sales promotion activities conducted by Griya Batik Mas use various types of promotion mix. The purpose of using various types of promotion mix is as an alternative type of promotion, if one type of promotion can not give maximum results, then use other types of promotion. Promotional activities that have been implemented aims to make the brand known to the public and can provide various information through these promotional activities. Of course every running a promotional strategy does not all go with as you wish. Every run of a business will appear constraints a constraint that may not affect big cuku. Constraints yag faced by Griya Batik Mas is the ability to manage Social Media is still minimal, according to Mr. M. Hisyam, he is still looking for employees who are expected to help in managing social media so as to provide or upload photos of products or anything about Griya Batik Mas routinely, so more people will be able to see.

As for some suggestions that are proposed are as follows :

1. In the process of promoting Griya Batik Mas, it is expected not to change the pattern of promotional strategies that already exist. If there is a new promotional strategy, it is good to try but still maintain the old promotional strategy. Griya Batik Mas must continue to improve employee performance, continue to innovate in creating products, goods and services. And still maintain the characteristic of pekalongan batik without forgetting aspects of excellence of a product, visitor convenience, excellent service provided to satisfy customers.

2. Improving Griya Batik Mas promotion strategy through social media, this is caused by the behavior of modern society who prefer to shop online. It would be nice if social media Instagram and Facebook not only as a means of promotion alone, but the customers who see can directly buy online. Continue to maintain Griya Batik Mas sales system that merges with MarketPlace Zalora Indonesia, this can increase sales and customer confidence in the product Griya Batik Mas. 


\section{REFERENCES}

Anditia, Dita. (2014). “Analisis Visual Motif dan Makna Simbolis Batik Majalengka”. (Skripsi S1-Progdi Pendidikan Sejarah). Majalengka: Universitas Pendidikan Indonesia

Angipora, M. P. (2007). "Dasar-dasar Pemasaran". PT Raja Grafindo ersada, Jakarta.

Ariyanti, Tria. (2014). "Pengaruh Strategi Promosi Terhadap Penjualan Produk di PT. United Indo Surabaya". Dalam Jurnal Ilmu dan Riset Managemen. Vol. 3, No. 10.

Boong hee, Yoo dan Naveen Donthu Sungho Lee. (2000). "An examination of selected marketing mix elements and brand equity". Journal of The Academy Marketing Studies. Volume 28 no. 2 Academy Of Marketing Science, 2000.

Bryson, J.M. (2003). "Strategic Perencanaan Strategis Bagi Organisasi Sosial, Edisi ke-1, M. Miftahuddin, Cetakan ke-5. Yogyakarta: Pustaka Pelajar.

Constantinides. E. (2006). "The Marketing Mix Revisited: Towards the 21 st century Marketing". Journal of Marketing Management. Volume 22, number 3. WestBurn Publisher Ltd.

Effendy, Onong Uchjana. (1993). "Ilmu, Teori \& Filsafat Komunikasi”. Bandung : PT. Citra Aditya Bakti.

Jefkins, F. (2004). Periklanan. Edisi Ketiga. Erlangga, Jakarta.

Kotler, P. (2008). "Manajemen Pemasaran”. Edisi Milenium Jilid 2. PT Prenhallindo, Jakarta.

Moleong, L. J. (2005). 'Metode Penelitian Kualitatif”. Bandung: Remaja Rosdakarya.

Permas, A., C. Hasibuan-Sedyono, L.H. Pranoto, dan T. Saputro. 2003. Manajemen Organisasi Seni Pertunjukan. Jakarta: Pustaka Binaman Pressindo.

Prisgunanto, Ilham. (2006). Komunikasi Pemasaran: Strategi dan Taktik. Bogor: Ghalia Indonesia.

Rachmadi, F. (1994). Public Relation Dalam Teori dan Praktek. Jakarta: Gramedia Pustaka Utama.

Rakhmat, Djalaludin. (2001). "Metode Penelitian Komunikasi”. Bandung: PT. Remaja Rosdakarya.

Rangkuti, Freddy. (2009). Measuring Custumer Satisfaction : Teknik Mengukur dan Strategi Meningkatkan Kepuasan Pelanggan. Jakarta: PT. Gramedia Pustaka Utama.

Ruslan, Rosady. (2005). Manajemen Public Relation dan Media Komunikasi: Konsep dan Aplikasinya, Jakarta: Rajawali Pers.

Saladin, D. (1991). Unsur-unsur Inti Pemasaran dan Manajemen Pemasaran. Bandung: Mandar Maju.

Salusu, (2002). Pengambilan Keputusan Strategik Untuk Organisasi Publik dan Organisasi Non Profit, Jakarta: PT. Grasindo.

Shimp,T.A. (2003). Periklanan dan Promosi: Aspek Tambahan Komunikasi Pemasaran Terpadu. Erlangga, Jakarta.

Soekanto, S. (1982). Kesadaran Hukum dan Kepatuhan Hukum, Jakarta: Rajawali.

Soemanagara. (2006). Strategic Marketing Communication, Bandung: CV. Alfabeta.

Sugiyono. (2009). Metode Penelitian Kuantitatif dan Kualitatif. Bandung: CV.Alfabeta.

Tjiptono, Fandy. (2002). Strategi Pemasaran, Yogyakarta: Penerbit Andi.

Uyung Sulaksana. (2003). Integrated Marketing Kommunications. Yogyakarta: Pustaka Pelajar.

Winardi. (1989). Ilmu dan Seni Menjual, Bandung: Penerbit Nova. 